\title{
RASIO PASAR, PROFITABILITAS DAN LIKUIDITAS BERPENGARUH TERHADAP HARGA SAHAM PADA PERUSAHAAN OTOMOTIF DAN KOMPONEN
}

\author{
Ni Kadek Anggun Pramesthi Dewi Sujata1 \\ Ida Bagus Badjra \\ ${ }^{1,2}$ Fakultas Ekonomi dan Bisnis Universitas Udayana, Bali, Indonesia \\ email: anggunpramesthi98@yahoo.com
}

\begin{abstract}
ABSTRAK
Harga saham sangat penting bagi perusahaan karena harga saham merupakan salah satu alasan utama yang mendasari para investor untuk membeli saham sebagai bentuk investasinya pada perusahaan. Harga saham suatu perusahaan selalu mengalami pergerakan naik atau turun. Pergerakan naik pada harga saham inilah yang dapat memberikan keuntungan bagi para investor. Tujuan dari penelitian ini adalah untuk menganalisa signifikansi pengaruh Rasio Pasar, Profitabilitas dan Likuiditas terhadap harga saham. Penelitian ini dilakukan pada Perusahaan Otomotif dan Komponen yang terdaftar di Bursa Efek Indonesia (BEI) periode 2016-2018. Jumlah sampel penelitian ini adalah 13 perusahaan, dengan metode sampling jenuh yaitu semua populasi dijadikan sampel. Pengumpulan data dilakukan dengan metode observasi non partisipan yaitu melalui data laporan keuangan yang dipublikasikan pada www.idx.co.id. Hasil penelitian ini menemukan bahwa Rasio Pasar, Profitabilitas dan Likuiditas berpengaruh signifikan terhadap Harga Saham.

Kata kunci : Rasio Pasar, Profitabilitas, Likuiditas dan Harga Saham
\end{abstract}

\begin{abstract}
Share prices are very important for companies because stock prices are one of the main reasons underlying investors to buy shares as a form of investment in the company. A company's stock price always experiences up or down movements. This upward movement in stock prices can provide benefits for investors. The purpose of this study is to analyze the significance of the effect of Market Ratio, Profitability and Liquidity on stock prices. This research was conducted at Automotive and Component Companies listed on the Indonesia Stock Exchange (BEI) 2016-2018 period. The total sample of this research is 13 companies, with saturated sampling method that is all populations are sampled. Data collection is done by non-participant observation methods, namely through financial statement data published on www.idx.co.id. The results of this study found that Market, Profitability and Liquidity Ratios have a significant effect on stock prices.

Keywords: Market Ratios, Profitability, Liquidity and Stock Prices
\end{abstract}




\section{PENDAHULUAN}

Salah satu ciri perekonomian modern adalah adanya pasar modal sebagai salah satu elemen sistem ekonomi yang turut memacu pertumbuhan dan perkembangan ekonomi dan bisnis (Azmy, 2019). Kondisi perekonomian suatu negara telah maju ditandai dengan pesatnya perkembangan industri pasar modal maupun pasar saham. Tujuan utama sebuah perusahaan yaitu penciptaan nilai dan pencapaian hasil atau prestasi yang memuaskan melalui peningkatan profitabilitas dan kekayaan pemegang saham. Penciptaan nilai tercipta saat perusahaan menghasilkan atau mempertahankan tingkat pengembalian yang lebih dari biaya modal. Prestasi perusahaan dapat dinilai dari besarnya kinerja keuangan selama periode tertentu. Penilaian kinerja keuangan merupakan salah satu cara yang dapat dilakukan oleh pihak manajemen agar dapat memenuhi kewajibannya terhadap para investor dan mencapai tujuan yang telah ditetapkan oleh perusahaan.

Secara umum pengertian pasar modal adalah tempat berbagai pihak, khususnya pada perusahaan yang menjual saham dan obligasi, dengan tujuan dari hasil penjualan tersebut nantinya akan dipergunakan sebagai tambahan atau memperkuat modal perusahaan (Susyanti \& Salim, 2019). Pasar modal adalah sarana yang mempertemukan penjual dan pembeli dana. Tempat penawaran penjualan efek ini dilaksanakan berdasarkan satu bentuk lembaga resmi yang disebut bursa efek. Menurut Hidayat (2018) kinerja keuangan adalah hasil pencapaian suatu perusahaan dalam menjalankan operasionalnya. Dalam kinerja keuangan dapat dilihat keefektifan manajemen perusahaan dalam memfungsikan segala unsur yang ada dalam perusahaan. Analisis kinerja keuangan sangat penting dilakukan untuk mengetahui apakah perusahaan tersebut merupakan perusahaan yang sehat dan mampu menghasilkan laba sehingga investor dapat tertarik untuk menginvestasikan dana yang mereka miliki. Semakin banyak investor yang tertarik membeli saham maka harga saham akan naik. Laporan keuangan digunakan sebagai pertimbangan dalam menentukan harga saham. Harga saham merupakan cerminan kondisi suatu perusahaan dimana harga saham yang terjadi di bursa pada saat tertentu. Harga saham yang tinggi akan memberikan return bagi para investor berupa capital gain yang akhirnya akan berpengaruh terhadap citra perusahaan.

Tujuan perusahaan melakukan investasi saham adalah untuk memaksimalkan kesejahteraan pemegang saham dengan cara memaksimalkan nilai saham perusahaan yang pada akhirnya akan mencerminkan harga saham tersebut (Mudjiyono, 2012). Investasi dalam bentuk saham sebenarnya memiliki risiko yang tinggi sesuai dengan prinsip investasi yaitu low risk, low return, high risk, high return. Seorang investor hendaknya benar-benar memahami tentang harga saham dan kerap melakukan analisis harga saham terlebih dahulu agar tidak salah berinvestasi karena pergerakan harga suatu saham tidak dapat diperkiraan secara pasti. Harga saham sangat penting bagi perusahaan karena harga saham merupakan salah satu alasan utama yang mendasari para investor untuk membeli saham sebagai bentuk investasinya pada perusahaan. Investasi tersebut tentunya sangat diperlukan oleh perusahaan, sebab dalam menjalankan usahanya dibutuhkan dana yang tidak sedikit (Paramitasari, 2014). 
Harga saham dapat dipengaruhi oleh faktor eksternal dan faktor internal. Faktor eksternal yang mempengaruhi harga saham adalah kondisi perekonomian, kebijakan pemerintah dan tingkat suku bunga, sedangkan faktor internal yang mempengaruhi harga saham adalah EPS (earning per share), PER (price to earning ratio), PBV (price to book value), ROE (Return On Equity), DY (dividend yield), DER (Debt to Equity Ratio), TAT (Total Asset Turnover), CR (current ratio) (Pratama, 2019). Penelitian ini menggunakan rasio pasar dengan alat ukur EPS karena EPS sering digunakan untuk menilai profitabilitas dan risiko yang terkait dengan keuntungan dan juga penilaian tentang harga saham (Watung \& Ilat, 2016). Rasio profitabilitas dengan alat ukur ROE karena rasio ini dapat mengukur seberapa besar perusahaan memperoleh keuntungan dengan menggunakan ekuitas yang dimiliki perusahaan (Pomartia et al. , 2019). Rasio likuiditas dengan alat ukur CR karena CR merupakan ukuran yang paling umum digunakan untuk mengetahui kesanggupan memenuhi kewajiban jangka pendek (Rahmadewi \& Abundanti, 2018).

Rasio pasar adalah rasio yang digunakan untuk mengukur jumlah uang yang dibayar oleh penanam modal untuk setiap rupiah pendapatan perusahaan (Sari \& Herawati, 2019). Dalam penelitian ini rasio pasar yang digunakan adalah EPS (Earning Per Share), yaitu rasio untuk mengukur keuntungan yang diberikan perusahaan kepada investor atas setiap lembar saham yang dimiliki. Semakin tinggi EPS maka investor menganggap prospek perusahaan sangat baik untuk kedepannya sehingga mempengaruhi tingkat permintaan terhadap saham perusahaan tersebut (Dewi \& Suayana, 2013). Rasio ini membandingkan antara harga saham yang diperoleh dari pasar modal dan laba per lembar saham yang diperoleh pemilik perusahaan yang disajikan di laporan keuangan (Husnan \& Pudjiastusi, 2012:78).

Rasio pasar merupakan indikator untuk mengukur tinggi rendahnya suatu saham, serta dapat membantu investor dalam mencari saham yang memiliki potensi keuntungan dividen yang besar sebelum melakukan penanaman modal berupa saham. Namun rasio pasar tidak mempunyai ukuran yang menunjukan tingkat efesiensi rasio serta tidak dapat mencerminkan kinerja keuangan perusahaan secara keseluruhan jika dilihat berdasarkan harga saham maupun jika dipergunakan oleh pihak manajemen perusahaan (Farid, 2013). Gustmainar \& Mariani (2018) menemukan Earning per Share (EPS) berpengaruh positif dan signifikan terhadap harga saham sesuai dengan pendapat Nurfadillah (2011), Sha et al. (2017), sedangkan Rahmadewi \& Abundanti (2018) menemukan Earning per Share (EPS) tidak berpengaruh signifikan terhadap harga saham.

Rasio Profitabilitas adalah kemampuan perusahaan memperoleh laba atau ukuran efektivitas pengelolaan manajemen perusahaan (Wiagustini, 2017:5). Dalam penelitian ini alat ukur profitabilitas adalah ROE, rasio ini mengukur seberapa banyak keuntungan yang menjadi hak pemilik modal sendiri, karena rasio ini dipergunakan angka laba setelah pajak (Husnan \& Pudjiastuti, 2015:76). ROE yaitu laba bersih, para pemegang saham ingin memperoleh tingkat pengembalian tinggi dan ROE menunjukan tingkat pengembalian yang akan diterima. ROE tinggi, maka harga saham juga akan tinggi dan peningkatan ROE akan meningkatkan harga saham (Wulandari \& Badjra, 2019). 
Mareta et al. (2013) menyatakan bahwa ROE merupakan suatu pengukuran dari penghasilan (income) yang tersedia bagi pemilik perusahaan baik pemegang saham biasa maupun pemegang saham preferen atas modal yang diinvestasikan di dalam perusahaan. Anita et al. (2017) menemukan bahwa profitabilitas berpengaruh positif signifikan terhadap harga saham hal ini berarti profitabilitas dapat meningkatkan harga saham. Didukung oleh penelitian Wehantouw, dkk. (2017), Arifin \& Agustami (2017), menemukan bahwa profitabilitas berpengaruh positif signifikan terhadap harga saham. Perbedaan hasil penelitian dikemukakan oleh Dewi dkk. (2016) serta Rahmadewi \& Abundanti (2018) yang menemukan bahwa profitabilitas tidak berpengaruh signifikan terhadap harga saham.

Rasio Likuiditas merupakan kemampuan perusahaan untuk memenuhi kewajiban financialnya dalam jangka pendek dengan dana lancar yang tersedia (Wiagustini, 2017:76). Sebagai indikator maka digunakan curret ratio (CR) yang dapat mengukur seberapa jauh aktiva lancar perusahaan bisa dipakai untuk memenuhi kewajiban lancarnya (Husnan \& Pudjiastuti, 2015:72), dengan kata lain seberapa banyak aktiva lancar yang tersedia untuk menutupi kewajiban jangka pendek yang segera jatuh tempo. Rasio Likuiditas ini sangat penting bilamana investor ingin mengetahui tingkat likuid perusahaan dalam penyediaan kas perusahaan, karena rasio ini merupakan ukuran tingkat keamanan dalam memenuhi hutang jangka pendek.

Menurut Wiagustini (2017:76) agar perusahaan selalu likuid, maka posisi dana lancar yang tersedia harus lebih besar daripada utang lancar sehat. Oleh karena itu, perlu pengaturan, menjaga dan memelihara likuiditas yang baik untuk menjaga kredibilitas kepada kreditur. Pada penelitian ini menggunakan Current Ratio karena rasio ini dapat digunakan untuk mengukur kemampuan perusahaan membayar utang jangka pendek dengan menggunakan aktiva (Imelda et al., 2018). Penelitian yang dilakukan oleh Rahayu \& Dana (2016) mendapatkan hasil likuiditas berpengaruh positif signifikan terhadap harga saham hal ini berarti investor akan tertarik pada perusahaan yang memiliki tingkat likuiditas yang baik. Penelitian Arifin \& Agustami (2017) menemukan pengaruh positif signifikan likuiditas terhadap harga saham. Perbedaan hasil penelitian ditemukan pada Rahmadewi \& Abundanti (2018) yang menemukan bahwa likuiditas berpengaruh negatif signifikan terhadap harga saham.

Perusahaan Otomotif dan Komponen merupakan perusahaan yang berkembang seiring dengan perkembangan jaman dan teknologi. Masyarakat Indonesia umumnya sangat konsumtif terhadap teknologi otomotif. Daya beli masyarakat Indonesia mendorong Perusahaan Otomotif dan Komponen yang terdaftar di Bursa Efek Indonesia (BEI) untuk memberikan kualitas terbaik mereka yang tentunya akan menarik banyak pihak salah satunya adalah investor, dengan kualitas produk yang baik serta daya beli konsumen yang tinggi terhadap Perusahaan Otomotif dan Komponen tentunya para investor akan tertarik dan menaruh sahamnya pada perusahaan tersebut. Berikut disajikan data harga saham perusahaan Otomotif dan Komponen yang terdaftar di Bursa Efek Indonesia dari tahun 2016-2018 
Tabel 1.

Harga Saham Perusahaan Otomotif dan Komponen (Closing)

\begin{tabular}{lllccc}
\hline \multirow{2}{*}{ No } & \multirow{2}{*}{ Kode Perusahaan } & Nama Perusahaan & \multicolumn{3}{c}{ Harga (Rp) } \\
& & & $\mathbf{2 0 1 6}$ & $\mathbf{2 0 1 7}$ & $\mathbf{2 0 1 8}$ \\
\hline 1 & ASII & Astra International Tbk & 8.275 & 8.300 & 8.225 \\
2 & AUTO & Astra Otoparts Tbk & 2.050 & 2.060 & 1.470 \\
3 & BOLT & Garuda Metalindo Tbk & 805 & 985 & 970 \\
4 & BRAM & Indo Kordsa Tbk & 6.675 & 7.375 & 6.100 \\
5 & GDYR & Goodyear Indonesia Tbk & 1.920 & 1.700 & 1.940 \\
6 & GJTL & Gajah Tunggal Tbk & 1.070 & 680 & 650 \\
7 & IMAS & Indomobil Sukses International Tbk & 1.310 & 840 & 2.160 \\
8 & INDS & Indospring Tbk & 810 & 1.260 & 2.220 \\
9 & LPIN & Multi Prima Sejahtera Tbk & 5.400 & 1.305 & 995 \\
10 & MASA & Multistrada Arah Sarana Tbk & 270 & 280 & 720 \\
11 & NIPS & Nipress Tbk & 354 & 500 & 364 \\
12 & PRAS & Prima alloy steel Universal Tbk & 170 & 220 & 177 \\
13 & SMSM & Selamat Sempurna Tbk & 980 & 1.255 & 1.400 \\
\hline Sumber: Data Diolah, 2019 & & & &
\end{tabular}

Pada Tabel 1. harga saham diatas terlihat bahwa terjadi perubahan yang cukup fluktuatif selama periode. Harga saham perusahaan ASII mengalami perubahan yang berfluktuatif pada tahun 2016 perusahaan ASII memperoleh harga saham sebesar Rp. 8.275 mengalami peningkatan pada tahun 2017 sebesar Rp. 8.300 dan mengalami penurunan hingga Rp. 8.225. Harga saham perusahaan AUTO pada tahun 2016 memperoleh harga saham sebesar Rp. 2.050 mengalami peningkatan pada tahun 2017 sebesar Rp. 2.060 dan mengalami penurunan hingga Rp. 1.470. Harga saham perusahaan BOLT pada tahun 2016 memperoleh harga saham sebesar Rp. 805 mengalami peningkatan pada tahun 2017 sebesar Rp. 985 dan mengalami penurunan hingga Rp. 970. Harga saham perusahaan BRAM pada tahun 2016 memperoleh harga saham sebesar Rp. 6.675 mengalami peningkatan pada tahun 2017 sebesar Rp. 7.375 dan mengalami penurunan hingga Rp. 6.100.

Harga saham perusahaan GDYR pada tahun 2016 memperoleh harga saham sebesar Rp. 1920 mengalami penurunan pada tahun 2017 hingga Rp. 1.700 dan mengalami peningkatan sebesar Rp. 1.940. Harga saham perusahaan GJTL pada tahun 2016 memperoleh harga saham sebesar Rp. 1.070 mengalami penurunan pada tahun 2017 hingga Rp. 680 dan mengalami penurunan lagi hingga Rp. 650. Harga saham perusahaan IMAS pada tahun 2016 memperoleh harga saham sebesar Rp. 1.310 mengalami penurunan pada tahun 2017 hingga Rp. 840 dan mengalami peningkatan sebesar Rp. 2.160. Harga saham perusahaan INDS pada tahun 2016 memperoleh harga saham sebesar Rp. 810 mengalami peningkatan pada tahun 2017 sebesar Rp. 1.260 dan mengalami peningkatan lagi sebesar Rp. 2.220.

Harga saham perusahaan LPIN pada tahun 2016 memperoleh harga saham sebesar Rp. 5.400 mengalami penurunan pada tahun 2017 hingga Rp. 1.305 dan 
mengalami penurunan lagi hingga Rp. 995. Harga saham perusahaan MASA pada tahun 2016 memperoleh harga saham sebesar Rp. 270 mengalami peningkatan pada tahun 2017 hingga Rp. 280 dan mengalami peningkatan lagi hingga Rp. 720. Harga saham perusahaan NIPS pada tahun 2016 memperoleh harga saham sebesar Rp. 354 mengalami peningkatan pada tahun 2017 hingga Rp. 500 dan mengalami penurunan hingga Rp. 364. Harga saham perusahaan PRAS pada tahun 2016 memperoleh harga saham sebesar Rp. 170 mengalami peningkatan pada tahun 2017 sebesar Rp. 220 dan mengalami penurunan hingga Rp. 177.

Harga saham perusahaan SMSM pada tahun 2016 memperoleh harga saham sebesar Rp. 980 mengalami peningkatan pada tahun 2017 hingga Rp. 1.255 dan mengalami peningkatan lagi hingga Rp. 1.400. Perusahaan Otomotif dan Komponen di Bursa Efek Indonesia dari tahun 2016-2018 mengalami perkembangan yang berfluktuatif dan perbedaan hasil penelitian terdahulu menjadi dasar dilakukannya penelitian lebih lanjut mengenai pengaruh rasio pasar, profitabilitas, dan likuiditas. Terhadap harga saham pada Perusahaan Otomotif dan Komponen yang terdaftar di Bursa Efek Indonesia (BEI).

Berdasarkan rumusan masalah diatas, maka yang menjadi tujuan dari penelitian ini adalah Untuk menganalisa signifikansi pengaruh rasio pasar terhadap harga saham pada perusahaan otomotif dan komponen periode 2016-2018, Untuk menganalisa signifikansi pengaruh profitabilitas terhadap harga saham pada perusahaan otomotif dan komponen periode 2016-2018 dan Untuk menganalisa signifikansi pengaruh likuiditas terhadap harga saham pada perusahaan otomotif dan komponen periode 2016-2018.

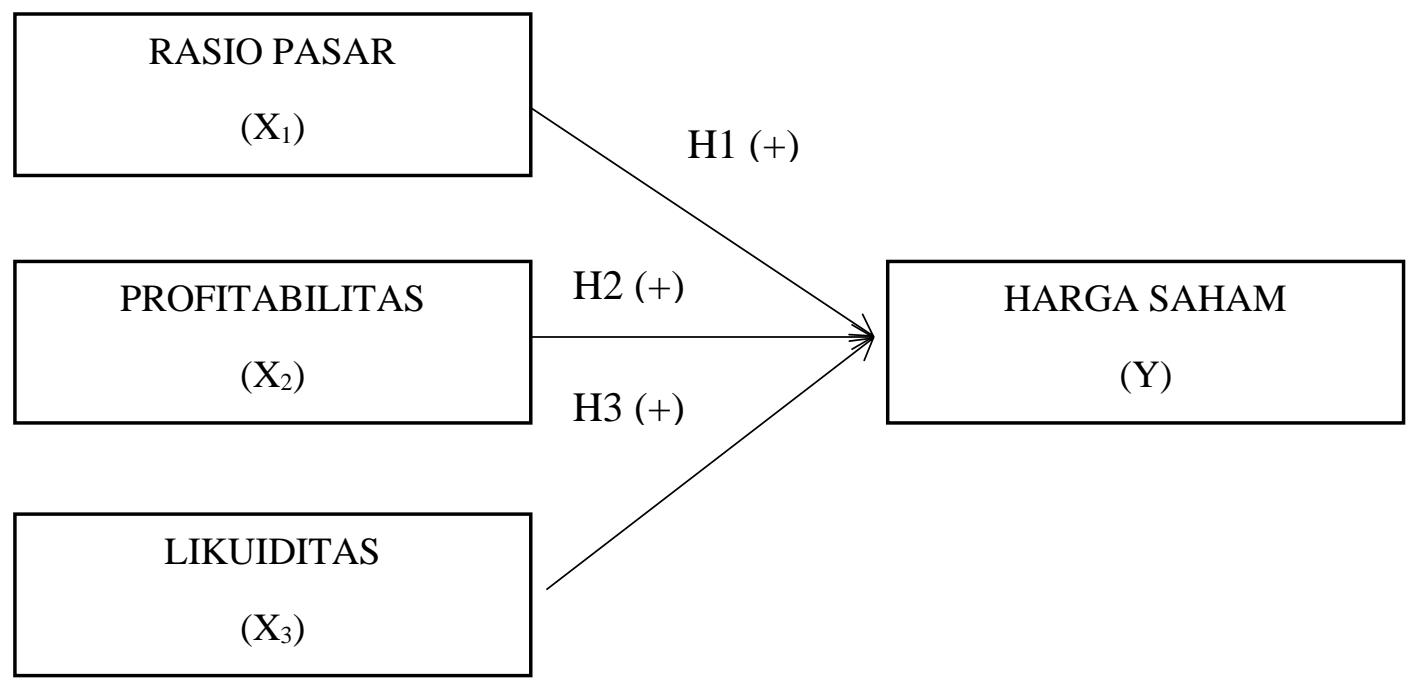

\section{Gambar 1. Kerangka Konseptual Penelitian}

Earning per Share (EPS) menunjukan laba bersih yang berhasil diperoleh perusahaan untuk setiap lembar saham selama satu periode tertentu yang akan dibagikan kepada semua pemegang saham. Kenaikan atau penurunan EPS dari tahun ke tahun adalah ukuran penting untuk mengetahui baik tidaknya operasional yang dilakukan oleh perusahaan. Semakin tinggi EPS, harga saham 
cenderung naik. EPS yang meningkat taraf kemakmuran investor dan hal ini akan mendorong investor untuk menambah jumlah modal yang ditanamkan pada perusahaan tersebut. Pada akhirnya peningkatan jumlah permintaan terhadap saham mendorong harga saham juga ikut naik. Menurut Gustmainar \& Mariani (2018), Yuliza (2018), Nalurita (2019), Viet Ha et al. (2018), Idawati \& Wahyudi (2015), Utami \& Darmawan (2019), Warrad (2017), Earning per Share (EPS) berpengaruh positif dan signifikan terhadap harga saham sesuai dengan pendapat (Sha et al., 2017) bahwa EPS berpengaruh positif dan signifikan terhadap harga saham.

$\mathrm{H}_{1}$ : Earning per Share berpengaruh positif dan signifikan terhadap harga saham.

Profitabilitas akan diukur berdasarkan Return on Equity (ROE). ROE merupakan rasio keuangan yang digunakan untuk mengukur tingkat keberhasilan perusahaan dalam menghasilkan laba bagi para pemegang saham. ROE dianggap sebagai representasi dari kekayaan pemegang saham atau nilai perusahaan . Peningkatan rasio ROE umumnya diikuti dengan kenaikan harga saham (Febrioni, 2016). Berdasarkan signaling theory, nilai ROE dapat memberikan sinyal positif bagi para investor. Semakin tinggi ROE menunjukan kinerja perusahaan dalam mengelola modalnya untuk menghasilkan keuntungan bagi para pemegang saham semakin baik. Ini menunjukan bahwa perusahaan tersebut mampu secara efektif dan efisien menggunakan modal dari pemegang saham dalam memperoleh laba.

Meningkatnya laba bersih perusahaan maka akan meningkatkan nilai ROE sehingga akan menarik investor untuk membeli saham tersebut yang akhirnya harga saham di perusahaan tersebut akan mengalami kenaikan. Anita et al. (2017) mengemukakan bahwa profitabilitas berpengaruh positif signifikan terhadap harga saham hal ini berarti profitabilitas dapat meningkatkan harga saham. Didukung oleh penelitian Wehantouw, dkk. (2017), Arifin \& Agustami, (2017), Kumalasari \& Pratikto (2018), Hasan (2018), Rosikah (2018), Kai et al. (2018), Anwar \& Rahmalia (2019), Asmirantho \& Somantri (2017) menemukan bahwa profitabilitas berpengaruh positif signifikan terhadap harga saham.

$\mathrm{H}_{2}$ : ROE berpengaruh positif dan signifikan terhadap harga saham

Penelitian ini, untuk mengukur likuiditas perusahaan dalam penelitian ini menggunakan Current Ratio (CR). Alasan menggunakan CR sebagai indikator dari rasio likuiditas karena rasio tersebut merupakan rasio yang mengukur tingkat kemampuan perusahaan dalam memenuhi kewajiban jangka pendek yang telah jatuh tempo (Idamanti, 2013). Sebagai indikator maka digunakan current ratio yang dapat mengukur kemampuan perusahaan dalam membayar kewajiban jangka pendek atau utang yang segera jatuh tempo pada saat ditagih secara keseluruhan atau seberapa banyak aktiva lancar yang tersedia untuk menutupi kewajiban jangka pendek segera jatuh tempo.

Semakin besar perbandingan aktiva lancar dan kewajiban lancar, semakin tinggi kemampuan perusahaan menutupi kewajiban jangka pendeknya. CR yang rendah biasanya dianggap menunjukan terjadi masalah dalam likuiditas, sebaliknya CR yang terlalu tinggi juga kurang baik, karena menunjukan banyaknya dana menganggur yang pada akhirnya dapat mengurangi kemampuan perusahaan dalam menghasilkan laba (Sawir, 2012:10). Kemampuan perusahaan dalam membayar hutang pada saat jatuh tempo membuat daya tarik atau minat 
investor atas saham tersebut meningkat sehingga permintaan atas saham perusahaan tersebut juga meningkat. Hal in menyebabkan harga saham dari perusahaan ikut meningkat. Rasio likuiditas ini sangat penting bilamana investor ingin mengetahui tingkat likuid perusahaan dalam penyediaan kas perusahaan, karena rasio ini merupakan ukuran tingkat keamanan dalam memenuhi hutang jangka pendek (Asman et al., 2015). CR merupakan salah satu ukuran likuiditas yang bertujuan untuk mengukur kemampuan perusahaan dalam memenuhi kewajiban jangka pendeknya dengan asset lancar yang dimilikinya

Penelitian yang dilakukan oleh Rahayu \& Dana (2016) mendapatkan hasil likuiditas berpengaruh positif signifikan terhadap harga saham hal ini berarti investor akan tertarik pada perusahaan yang memiliki tingkat likuiditas yang baik. Penelitian Arifin \& Agustami (2017) Zuhroh (2019), Sitorus \& Elinarty (2017) dan Igbinosa \& Uhunmwangho (2019) menemukan pengaruh positif signifikan likuiditas terhadap harga saham.

$\mathrm{H}_{3}$ : Likuiditas berpengaruh positif dan signifikan terhadap harga saham

\section{METODE PENELITIAN}

Berdasarkan permasalahan yang diteliti, penelitian ini digolongkan pada penelitian asosiatif, yaitu penelitian yang bertujuan untuk mengetahui hubungan dari dua variabel atau lebih. Metode ini digunakan untuk mengetahui hubungan antara rasio keuangan Rasio Pasar, Profitabilitas, Likuiditas terhadap harga saham pada Perusahaan Otomotif dan komponennya yang terdaftar di Bursa Efek Indonesia (BEI). Lokasi penelitian ini dilakukan pada Perusahaan Otomotif dan Komponennya yang terdaftar di Bursa Efek Indonesia (BEI) dengan menggunakan laporan keuangan yang dipublikasikan pada website www.idx.co.id

Harga saham dalam penelitian ini merupakan nilai nominal dari suatu saham yang ditebitkan. Pihak pemegang saham selain mengharapkan keuntungan berupa deviden, keuntungan yang diharapkan adalah selisih harga saham. Harga saham dalam penelitian ini menggunakan harga saham penutupan (closing price) pada Perusahaan Otomotif dan Komponen yang terdaftar di Bursa Efek Indonesia (BEI), periode 2016-2018. Earning Per Share (EPS) dalam penelitian ini adalah kemampuan perusahaan untuk mendistribusikan pendapatan yang diperoleh kepada pemegang sahamnya. Satuan pengukuran EPS adalah persentase (\%) yang ditunjukan oleh laporan keuangan pada Perusahaan Otomotif dan Komponen yang terdaftar di Bursa Efek Indonesia (BEI) periode 2016-2018. EPS dapat dihitung dengan menggunakan rumus sebagai berikut (Wiagustini, 2017:81)

EPS $\frac{E A T}{\text { Jumlah Lembar Saham }} \times 100 \%$

Profitabilitas akan diukur menggunakan Return On Equity (ROE). ROE merupakan kemampuan dari modal sendiri untuk menghasilkan keuntungan bagi seluruh pemegang saham. Satuan pengukur ROE adalah persentase (\%) yang ditunjukan oleh laporan keuangan pada Perusahaan Otomotif dan Komponennya yang terdaftar di Bursa Efek Indonesia (BEI) periode 2016-2018 (Wiagustini, 2017:81). ROE dapat dihitung menggunakan rumus sebagai berikut: 
$\mathrm{ROE}=\frac{\text { Laba Bersih }}{\text { Modal Sendiri }} \times 100 \%$

Likuiditas mengukur kemampuan perusahaan untuk memenuhi kewajiban jangka pendeknya yang segera jatuh tempo. Pengukuran likuiditas diproksikan dengan Current Ratio (CR) dengan satuan rasio (Wiagustini, 2017:78) perbandingan antara aktiva lancar dengan hutang lancar perusahaan yang terdaftar di BEI periode 2016-2018. CR dinyatakan dalam bentuk persentase, yang secara sistematis dapat dirumuskan sebagai berikut:

Current Ratio $=$ $\frac{\text { Aktiva Lancar }}{\text { Pasiva Lancar }} \times 100 \%$

Populasi dalam penelitian ini adalah seluruh perusahaan sektor otomotif dan komponennya yang terdaftar di Bursa Efek Indonesia periode 2016-2018 yaitu sebanyak 13 perusahaan. Pemilihan sampel penelitian ini dilakukan dengan menggunakan metode sampling jenuh (sampling sensus). Sampling jenuh adalah tehnik penentuan sampel apabila semua anggota populasi digunakan sebagai sampel. Metode pengumpulan data yang digunakan dalam penelitian ini adalah pengumpulan data observasi non partisipan yaitu data laporan keuangan pada Perusahan Otomotif dan Komponen yang terdaftar di Bursa Efek Indonesia (BEI) periode 2016-2018 yang dipublikasikan pada website $w w w . i d x . c o . i d$

\section{HASIL DAN PEMBAHASAN}

Penelitian ini dilakukan pada perusahaan Otomotif dan Komponen yang terdaftar di Bursa Efek Indonesia (BEI) periode 2016-2018. Jumlah perusahaan pada periode ini adalah sebanyak 13 perusahaan, yaitu PT Astra International Tbk, PT Astra Otoparts Tbk, Pt Garuda Metalindo Tbk, Indo Kordsa Tbk, PT Goodyear Indonesia Tbk, PT Gajah Tunggal Tbk, Indomobil Sukses International Tbk, PT Indospring Tbk, Multi Prima Sejahtera Tbk, Mutistrada Arah Sarana Tbk, Nipress Tbk, Prima alloy steel Universal Tbk, dan Selamat Sempurna Tbk.

PT. Astra International Tbk tercatat di Bursa Efek Indonesia sejak tanggal 4 April 1990, perusahaan ini merupakan salah satu perusahaan besar yang menekuni bidang Automotive and Components. Pusat perusahaan ini bertempat di Jl. Jend Sudirman Kav.47-48 Jakarta 12930. Pada pembagian sahamnya perusahaan ini terdiri dari 50,09 \% milik Jardine Cycle dan Carriage Limited, kemudian sebesar 49,91\% milik masyarakat. PT. Astra Otoparts tercatat di Bursa Efek Indonesia sejak tanggal 15 Juni 1998, perusahaan ini merupakan salah satu perusahaan yang menekuni bidang Automotive and Components. Pusat perusahaan ini bertempat di J1. Jend. Sudirman Kav.47-48 Jakarta 12930. Pembagian saham perusahaannya terdiri dari 94,25\% milik PT Astra International Tbk, sisanya sebesar 4,35\% adalah milik masyarakat.

PT Garuda Metalindo Tbk tercatat di Bursa Efek Indonesia sejak tahun 1982, perusahaan ini merupakan salah satu perusahaan yang menekuni bidang Automotive and Components. Pusat perusahaan ini bertempat di Jl. Kapuk Kayu Besar No 23, RT.2/RW.2, Kamal Muara, Kec.Penjaringan, Kota Jakarta Utara 14470. PT Indo 
Kordsa Tbk tercatat di Bursa Efek Indonesia sejak tanggal 5 September 1990, perusahaan ini merupakan salah satu perusahaan yang menekuni bidang Automotive and Components. Pusat perusahaan ini bertempat di Jl. Yos Sudarso Kav. 89 Jakarta 14350. Pada pembagian sahamnya, telah memiliki pembagian sebesar $60,21 \%$ oleh Kordsa Global A S, kemudian sebesar 17,31\% adalah milik Robby Sumampow, kemudian sebesar 6,61\% adalah milik Robby Sumampow dan sebesar 5,61\% adalah milik PT Risjadsod Suryatama, sedangkan sebesar 48,99\% adalah milik masyarakat.

PT Goodyear Indonesia Tbk tercatat di Bursa Efek Indonesia sejak tanggal 22 Desember 1980 dan perusahaan ini menduduki bidang sektor Automotive and Components. Pusat perusahaan ini bertempat di J1. H.R. Rasuna SAID Kav.10, Jakarta 12950. Pembagian sahamnya terdiri dari The Goodyear Tire dan Rubber Company memiliki saham sejumlah $85,00 \%$ kemudian sebesar 9,02\% adalah milik Kalibesar Asri, sedangkan sisanya sebesar 5,98\% dimiliki oleh masyarakat. PT Gajah Tunggal tercatat di Bursa Efek Indonesia sejak tanggal 8 Mei 1990, perusahaan ini merupakan salah satu bidang Automotive and Components. Pusat perusahaannya berada di Jl. Jend Sudirman Kav.34-35 Jakarta. Pada pembagian sahamnya terdiri dari Denham Pte Ltd memiliki saham sebesar 49,70\% kemudian Compagnie Financiere Michelin memiliki saham sebesar 10,00\%, sedangkan sisanya sebesar 40,30 dimiliki oleh masyarakat.

Indomobil Sukses Internasional Tbk tercatat di Bursa Efek Indonesia pada tanggal 15 November 1993 dan menduduki sektor Automotive and Components. Pusat perusahaan ini terletak di Jl. Jend. Sudirman Kav 47-48 Jakarta 12930. Pembagian sahamnya terdiri dari 52,35\% adalah milik PT Cipta Sarana Duta Perkasa, kemudian saham sebesar $18,05 \%$ milik PT Tritunggal Intipermata, sedangkan sisanya sebesar $29,60 \%$ adalah milik masyarakat. Indospring Tbk tercatat di Bursa Efek Indonesia sejak tanggal 10 Agustus 1990 dan membidangi sektor Automotive and Components. Pusat perusahaan ini bertempat di Jl. K.H, Hasyim Ashari Jakarta 10150. Pembagian sahamnya terdiri dari 75,64\% milik Indoprima Gemilang, lalu sebesar 12,46\% adalah milik Indoprima Gemilang kemudian sisanya sebesar $11,98 \%$ adalah milik masyarakat.

Multi Prima Sejahtera Tbk tercatat di Bursa Efek Indonesia pada tanggal 5 Februari 1990 dan membidangi Automotive and Components. Pusat perusahaan bertempat di Jl. Jend. Gatot Subroto Kav. 35-36 Jakarta 12950. Pembagian sahamnya terdiri dari 52,00\$ adalah milik Pacific Asia Holding Ltd, sedangkan sisanya sebesar $75,00 \%$ adalah milik masyarakat. Multistrada Arah Sarana Tbk tercatat di Bursa Efek Indonesia sejak tanggal 9 Juni 2005 dan membidangi sektor Automotive and Components. Pusat perusahaan ini bertempat di Jl. Jend. Sudirman Kav. 47-48 Jakarta 12930. Pembagian saham perusahaan ini adalah 16,67\% adalah milik PT Central Sole Agency, kemudian saham 45,95\% adalah milik PVP XVIII Pte. Ltd, kemudia diikuti oleh kepemilikan saham sebesar $15,11 \%$ oleh Lunar Crescent International Inc, sedangkan sisanya sebesar $46,76 \%$ adalah milik masyarakat.

Nipress Tbk tercatat di Bursa Efek Indonesia pada tanggal 24 Juli1991 dan membidangi sektor Automotive and Components. Pusat perusahaan ini bertempat di Jl. H.R Rasuna Said Kav. 10 Jakarta, untuk pembagian sahamnya terdiri dari 
37,11\% milik Tritan Adhitama Nugraha, kemudian sebesar 6,07\% milik Haiyanto, kemudian diikuti oleh kepemilikan saham sebesar 5,95 oleh Robertus Tandiono, kemudian sebesar 5,45\% dimiliki oleh Ferry J. Robertus Tandiono, sedangkan sisanya sebesar $45,42 \%$ dimiliki oleh masyarakat. Prima Alloy Steel Universal Tbk tercatat di Bursa Efek Indonesia sejak tanggal 12 Juli 1990 dan membidangi Automotive and Components. Pusat perusahaan ini bertempat di Jl. Jend. Sudirman Kav. 47-48 Jakarta 12930. Pembagian sahamnya terdiri dari 45,24\% milik PT Enmaru Internasional, kemudian saham 5,91\% milik Ratnawati Sasangko, sedangkan sisanya sebesar $48,85 \%$ adalah milik masyarakat. Selamat Sempurna Tbk tercatat di Bursa Efek Indonesia sejak tanggal 9 September 1996 dan membidangi sektor Automotive and Components. Pusat perusahaan ini bertempat di Jl. M.H Thamrin No.51 Jakarta 103350. Pembagian sahamnya terdiri dari 58,13\% milik PT Adrindo Intiperkasa, sedangkan sisanya sebesar 41,87\% milik masyarakat.

Tabel 2.

Statistik Deskriptif

\begin{tabular}{cccccc}
\hline & N & Minimum & Maximum & Mean & Std. Deviation \\
\hline Harga saham $(\mathrm{Y})$ & 39 & 170.00 & 8300.00 & 2160.0000 & 2495.49102 \\
Rasio pasar $\left(\mathrm{X}_{1}\right)$ & 39 & -9.79 & 2394.26 & 233.3436 & 475.34408 \\
Profitabilitas $\left(\mathrm{X}_{2}\right)$ & 39 & .18 & 82.94 & 9.1226 & 14.21221 \\
Likuiditas $\left(\mathrm{X}_{3}\right)$ & 39 & 71.35 & 768.07 & 222.5179 & 163.02181 \\
Valid N (listwise) & 39 & & & & \\
\hline
\end{tabular}

Sumber: Data Diolah, 2019

Berdasarkan Tabel 2. statistik deskriptif dapat dilihat nilai minimum yang diperoleh adalah sebesar 170.00, nilai maksimum sebesar 8300.00, sedangkan nilai mean sebesar 2160.0000 dan nilai standar deviasi sebesar 2495.49102. Berdasarkan tabel statistik deskriptif dapat dilihat nilai minimum yang diperoleh adalah sebesar -9.79 , nilai maksimum sebesar 2394.26, sedangkan nilai mean sebesar 233.3436 dan nilai standar deviasi sebesar 475.34408. Berdasarkan tabel statistik deskriptif dapat dilihat nilai minimum yang diperoleh adalah sebesar 18 , nilai maksimum sebesar 82.94, sedangkan nilai mean sebesar 9.1226 dan nilai standar deviasi sebesar 14.21221. Berdasarkan tabel statistik deskriptif dapat dilihat nilai minimum yang diperoleh adalah sebesar 71.35, nilai maksimum sebesar 768.07, sedangkan nilai mean sebesar 222.5179 dan nilai standar deviasi sebesar 163.02181.

Nilai konstanta benilai positif sebesar 5.686. maka dapat diartikan apabila tidak terdapat pengaruh dari variabel lain atau variabel bebas, maka nilai konstan dari variabel harga saham (Y) adalah sebesar 5.686. Nilai koefisien variabel rasio pasar (X1) bernilai positif sebesar .152 maka artinya apabila nilai rasio pasar (X1) naik satu satuan maka harga saham (Y) akan naik sebesar .152, sehingga dapat disimpulkan bahwa rasio pasar (X1) berpengaruh positif terhadap harga saham (Y). Nilai koefisien variabel profitabilitas (X2) bernilai positif sebesar .278 maka artinya apabila nilai profitabilitas (X2) naik satu satuan maka harga saham (Y) akan naik sebesar .278, sehingga dapat disimpulkan bahwa 
profitabilitas (X2) berpengaruh positif terhadap harga saham (Y). Nilai koefisien variabel likuiditas (X3) bernilai positif sebesar .090 maka artinya apabila nilai likuiditas $\left(\mathrm{X}_{3}\right)$ naik satu satuan maka harga saham $(\mathrm{Y})$ akan naik sebesar .090, sehingga dapat disimpulkan bahwa likuiditas $\left(\mathrm{X}_{3}\right)$ berpengaruh positif terhadap harga saham (Y).

Tabel 3.

Hasil Analisis Regresi Linier Berganda

\begin{tabular}{ccccccc}
\hline & & \multicolumn{2}{c}{$\begin{array}{c}\text { Unstandardized } \\
\text { Coefficients }\end{array}$} & $\begin{array}{c}\text { Standardized } \\
\text { Coefficients }\end{array}$ & t & Sig. \\
\cline { 3 - 5 } & Model & $\mathrm{B}$ & Std. Error & Beta & & \\
\hline \multirow{2}{*}{1} & (constant) & 5.686 & 1.249 & & 4.553 & .000 \\
& Rasio pasar $\left(\mathrm{X}_{1}\right)$ & .152 & .054 & .400 & 2.803 & .008 \\
& Profitabilitas $\left(\mathrm{X}_{2}\right)$ & .278 & .130 & .369 & 2.137 & .040 \\
& Likuiditas $\left(\mathrm{X}_{3}\right)$ & .090 & .260 & .055 & 2.346 & .732 \\
\hline
\end{tabular}

Sumber: Data Diolah, 2019

Tabel 4.

Hasil Uji Normalitas

\begin{tabular}{llr}
\hline & & $\begin{array}{r}\text { Unstandardized } \\
\text { Residual }\end{array}$ \\
\hline $\mathrm{N}$ & Mean & 39 \\
Normal parameters ${ }^{\mathrm{a}, \mathrm{b}}$ & Std. Deviation & .0000000 \\
Most extreme differences & Absolute & .75988911 \\
& Positive & .123 \\
Test statistic & Negative & .116 \\
Asymp. Sig. (2-tailed) & & -.123 \\
\hline Sumber: Data Diolah, 2019 & & .123 \\
& & .141 \\
\hline
\end{tabular}

Sumber: Data Diolah, 2019

Hasil uji Kolmogorov-Smirnov menunjukkan bahwa nilai Asymp. Sig. (2tailed) yang dihasilkan adalah sebesar 0.141. Nilai yang dihasilkan ini lebih besar dari signifikan 0,05 sehingga dapat disimpulkan bahwa data mengikuti sebaran normal, oleh karena itu asumsi normalitas telah terpenuhi.

Tabel 5.

Hasil Uji Autokolerasi

\begin{tabular}{cccccc}
\hline Model & $\mathbf{R}$ & $\boldsymbol{R}$ Square & $\begin{array}{c}\text { Adjusted } \boldsymbol{R} \\
\text { Square }\end{array}$ & $\begin{array}{c}\text { Std. Error of the } \\
\text { Estimate }\end{array}$ & Durbin-Watson \\
\hline 1 & $.710^{\text {a }}$ & .504 & .461 & .79179 & $\underline{1.772}$ \\
\hline Sumber: Data Diolah, 2019 & & &
\end{tabular}

Tabel 5. menunjukan Nilai Durbin Watson (DW) sebesar 1.772. Berdasarkan tabel Durbin-Watson dengan N 39 dan banyak variabel bebas 3 
diperoleh nilai upper boung (dU) sebesar 1.657 dan 4 - dU sebesar 2.343. Dapat dilihat nilai DW berada di antara batas atau upper boung (dU) dan 4- dU, dengan demikian maka $\mathrm{H}_{\mathrm{o}}$ diterima atau tidak terjadi Autokorelasi.

\begin{tabular}{|c|c|c|c|c|c|c|}
\hline \multicolumn{7}{|c|}{$\begin{array}{c}\text { Tabel } 6 . \\
\text { Hasil Uji Heterokedastisitas }\end{array}$} \\
\hline & \multirow[b]{2}{*}{ Model } & \multicolumn{2}{|c|}{ Unstandardized Coefficients } & \multirow{2}{*}{$\begin{array}{c}\text { Standardized } \\
\text { Coefficients } \\
\text { Beta }\end{array}$} & \multirow[t]{2}{*}{$\mathbf{t}$} & \multirow[t]{2}{*}{ Sig. } \\
\hline & & B & Std. Error & & & \\
\hline \multirow[t]{4}{*}{1} & (constant) & 1.358 & .582 & & 2.334 & .025 \\
\hline & Rasio pasar $\left(\mathrm{X}_{1}\right)$ & -.008 & .025 & -.061 & -.308 & .760 \\
\hline & Profitabilitas $\left(\mathrm{X}_{2}\right)$ & .053 & .061 & .208 & .868 & .391 \\
\hline & Likuiditas $\left(\mathrm{X}_{3}\right)$ & -.143 & .121 & -.260 & -1.181 & .246 \\
\hline
\end{tabular}

Sumber: Data Diolah, 2019

Jika model tersebut diuji secara parsial maka tabel diatas menunjukkan bahwa semua variabel bebas yang digunakan pada penelitian rasio pasar $\left(\mathrm{X}_{1}\right)$ sebesar 0.760, profitabilitas $\left(\mathrm{X}_{2}\right)$ sebesar 0.391 dan likuiditas $\left(\mathrm{X}_{3}\right)$ sebesar 0.244 memiliki nilai lebih besar dari 0,05 sehingga dapat disimpulkan bahwa tidak terjadi heterokedasitas.

Tabel 7.

Hasil Uji Multikolinearitas

\begin{tabular}{lcc}
\hline & \multicolumn{2}{c}{ Collinearity Statistics } \\
Model & Tolerance & VIF \\
\hline 1 (constant) & & \\
Rasio pasar $\left(\mathrm{X}_{1}\right)$ & .698 & 1.432 \\
Profitabilitas $\left(\mathrm{X}_{2}\right)$ & .476 & 2.099 \\
Likuiditas $\left(\mathrm{X}_{3}\right)$ & .566 & 1.767 \\
\hline
\end{tabular}

Sumber: Data Diolah, 2019

Tabel 7. menunjukkan bahwa untuk semua variabel independen yang digunakan memiliki nilai tolerance lebih besar dari 0.10, rasio pasar $\left(\mathrm{X}_{1}\right)$ sebesar 0.698, profitabilitas $\left(\mathrm{X}_{2}\right)$ sebesar 0.476 dan likuiditas $\left(\mathrm{X}_{3}\right)$ sebesar 0.566. Nilai VIF yang dihasilkan lebih kecil dari 10 , rasio pasar $\left(\mathrm{X}_{1}\right)$ sebesar 1.432, profitabilitas $\left(\mathrm{X}_{2}\right)$ sebesar 2.099 dan likuiditas $\left(\mathrm{X}_{3}\right)$ sebesar 1.767 sehingga dapat disimpulkan bahwa tidak terjadi korelasi ganda (multikolinieritas) antar variabel independen, oleh karena itu asumsi multikolinieritas telah terpenuhi.

Berdasarkan Tabel 8. diperoleh nilai F hitung sebesar 11.832. Nilai F hitung ini lebih besar dari nilai $F$ tabel sebesar 2.87 dan nilai signifikansi F sebesar 0.000 nilai ini lebih kecil dari 0.05 , sehingga dapat disimpulkan bahwa terdapat pengaruh signifikan rasio pasar $\left(\mathrm{X}_{1}\right)$, profitabilitas $\left(\mathrm{X}_{2}\right)$ dan likuiditas $\left(\mathrm{X}_{3}\right)$ terhadap variabel terikat yaitu harga saham (Y) secara simultan. 
Tabel 8.

Hasil Uji Kelayakan Model (Uji F)

\begin{tabular}{ccccccc} 
& Model & Sum of Squares & df & Mean Square & F & Sig. \\
\hline 1 & Regression & 22.253 & 3 & 7.418 & 11.832 & .000 \\
& Residual & 21.942 & 35 & .627 & & \\
& Total & 44.196 & 38 & & & \\
\hline
\end{tabular}

Sumber: Data Diolah, 2019

Tabel 9.

Hasil Analisis Koefisien Determinasi $\left(\mathbf{R}^{2}\right)$

\begin{tabular}{cccccc}
\hline Model & R & R Square & $\begin{array}{c}\text { Adjusted R } \\
\text { Square }\end{array}$ & $\begin{array}{c}\text { Std. Error of the } \\
\text { Estimate }\end{array}$ & Durbin-Watson \\
\hline 1 & $.710^{\mathrm{a}}$ & .504 & .461 & .79179 & 1.772 \\
\hline Sumber: Data Diolah, 2019 & & & &
\end{tabular}

Nilai R square sebesar $0.461 \times 100 \%=461 \%$. Hal ini mengindikasikan bahwa harga saham $(\mathrm{Y})$ dijelaskan sebesar $461 \%$ oleh variabel rasio pasar $\left(\mathrm{X}_{1}\right)$, profitabilitas $\left(\mathrm{X}_{2}\right)$ dan likuiditas $\left(\mathrm{X}_{3}\right)$ sisanya dijelaskan oleh variabel lain yang tidak dimasukkan ke dalam model atau penelitian.

Setelah diuji secara parsial dengan menggunakan uji t, diperoleh nilai $\mathrm{T}$ hitung sebesar 2.803, nilai $\mathrm{T}$ hitung ini lebih besar dari nilai $\mathrm{T}$ table sebesar 2.030. Nilai signifikan sebesar 0.000 nilai ini lebih kecil dari 0.05 , sehingga dapat disimpulkan bahwa terdapat pengaruh signifikan secara parsial antara rasio pasar $\left(\mathrm{X}_{1}\right)$ terdahap harga saham $(\mathrm{Y})$. Setelah diuji secara parsial dengan menggunakan uji t, diperoleh nilai $\mathrm{T}$ hitung sebesar 2.137 , nilai $\mathrm{T}$ hitung ini lebih besar dari nilai $\mathrm{T}$ table sebesar 2.030. Nilai signifikan sebesar 0.000 nilai ini lebih kecil dari 0.05 , sehingga dapat disimpulkan bahwa terdapat pengaruh signifikan secara parsial antara profitabilitas $\left(\mathrm{X}_{2}\right)$ terdahap harga saham $(\mathrm{Y})$. Setelah diuji secara parsial dengan menggunakan uji t, diperoleh nilai $\mathrm{T}$ hitung sebesar 2.346, nilai $\mathrm{T}$ hitung ini lebih besar dari nilai T table sebesar 2.030. Nilai signifikan sebesar 0.009 nilai ini lebih kecil dari 0.05 , sehingga dapat disimpulkan bahwa terdapat pengaruh signifikan secara parsial antara likuiditas $\left(\mathrm{X}_{3}\right)$ terdahap harga saham $(\mathrm{Y})$.

Pengujian hipotesis pertama yaitu pengaruh rasio pasar terhadap harga saham memperoleh nilai koefisien regresi sebesar 0,152 dan nilai signifikansi sebesar 0,000 lebih kecil daripada taraf nyata 0,05 yang menunjukan bahwa variabel rasio pasar secara statistik berpengaruh positif signifikan terhadap harga saham pada perusahaan otomotif dan komponen. Nilai koefisien regresi sebesar 0,152 menggambarkan arah hubungan positif dan menunjukan bahwa setiap kenaikan satu persen tingkat rasio pasar akan menaikan harga saham sebesar 0,152 . Hasil penelitian ini konsisten dengan hasil penelitian terdahulu oleh Gustmainar \& Mariani (2018) Earning per Share (EPS) berpengaruh positif dan signifikan terhadap harga saham sesuai dengan pendapat Nurfadillah (2011), Sha et al. (2017).

Pengaruh hipotesis kedua yaitu pengaruh profitabilitas terhadap harga saham memperoleh nilai koefisien regresi sebesar 0,278 dan nilai signifikansi 0,000 lebih 
kecil dari taraf nyata 0,05 yang menunjukan bahwa variabel profitabilitas secara statistik berpengaruh positif dan signifikan terhadap harga saham pada perusahaan otomotif dan komponen. Nilai koefisien regresi sebesar 0,278 menggambarkan arah hubungan positif dan menunjukan bahwa setiap kenaikan satu persen tingkat profitabilitas akan menaikan harga saham sebesar 0,416 persen. Hasil penelitian ini konsisten dengan Anita et al. (2017) mengemukakan bahwa profitabilitas berpengaruh positif signifikan terhadap harga saham hal ini berarti profitabilitas dapat meningkatkan harga saham. Didukung oleh penelitian Wehantouw, dkk. (2017), Arifin \& Agustami (2017) menemukan bahwa profitabilitas berpengaruh positif signifikan terhadap harga saham.

Pengujian hipotesis ketiga yaitu pengaruh likuiditas herhadap harga saham memperoleh nilai koefisien regresi sebesar 0,090 dan nilai signifikansi sebesar 0,090 lebih kecil daripada taraf nyata 0,05 yang menunjukan bahwa variabel pajak secara statistik berpengaruh positif signifikan terhadap harga saham pada perusahaan otomotif dan komponen. Nilai koefisien regresi sebesar 0,090 menggambarkan arah hubungan yang positif dan menunjukan bahwa setiap kenaikan satu persen likuiditas akan menaikan harga saham sebesar 0,090. Hasil penelitian ini konsisten dengan penelitian Rahayu \& Dana (2016) mendapatkan hasil likuiditas berpengaruh positif signifikan terhadap harga saham hal ini berarti investor akan tertarik pada perusahaan yang memiliki tingkat likuiditas yang baik. Penelitian Arifin \& Agustami (2017) menemukan pengaruh positif signifikan likuiditas terhadap harga saham.

Berdasarkan penelitian ini diketahui bahwa variabel rasio pasar, profitabilitas dan likuiditas yang sesuai dengan teori yang ada sebelumnya yaitu rasio pasar, profitabilitas dan likuiditas berpengaruh positif signifikan terhadap harga saham. Rasio pasar, profitabilitas dan likuiditas berpengaruh positif terhadap harga saham. Hal ini menunjukan bahwa rasio pasar, profitabilitas dan likuiditas merupakan rasio keuangan yang diperhatikan investor dalam berinvestasi di pasar modal, sesuai dengan penelitian yang telah dilakukan oleh Gustmainar \& Mariani (2018), Sha et al. (2017), Anita et al. (2017), Wehantouw, dkk. (2017), Arifin \& Agustami, (2017), Rahayu \& Dana (2016). Penelitian ini menghasilkan informasi bahwa rasio pasar, profitabilitas dan likuiditas berpengaruh positif terhadap harga saham yang berarti investor memperhatikan rasio pasar, profitabilitas dan likuiditas dalam melakukan investasi. Semakin tinggi rasio pasar, profitabilitas dan likuiditas maka akan semakin tinggi juga minat investor dan perusahaan dalam menanamkan modal pada perusahaan, sehingga harga saham juga akan ikut naik.

\section{SIMPULAN}

Rasio pasar berpengaruh positif dan signifikan terhadap harga saham. Hal ini menunjukan peningkatan rasio pasar akan berdampak pada peningkatan harga saham. Profitabilitas berpengaruh positif dan signifikan terhadap harga saham. Hal ini menunjukan peningkatan profitabilitas akan berdampak pada peningkatan harga saham. Likuiditas berpengaruh positif dan signifikan terhadap harga saham. Hal ini menunjukan peningkatan likuiditas akan berdampak pada peningkatan harga saham. 
Bagi perusahaan, untuk menarik minat investor perusahaan perlu melakukan pengambilan kebijakan finansial. Perusahaan hendaknya meningkatkan kinerja perusahaan tiap tahunnya agar mampu bersaing dalam memperoleh kepercayaan dari investor sehingga memudahkan untuk memperoleh modal. Peningkatan kinerja dilakukan guna meningkatkan kinerja perusahaan melalui usaha meningkatkan rasio-rasio keuangan seperti rasio pasar, profitabilitas dan likuiditas serta memberikan informasi-informasi yang lebih jelas sehingga bisa dimanfaatkan investor untuk dijadikan pedoman dalam pengambilan keputusan investasinya. Bagi investor sebaiknya memperhatikan informasi-informasi yang dikeluarkan oleh perusahaan yaitu rasio pasar, profitabilitas dan likuiditas karena informasi tersebut berpengaruh terhadap harga saham dan agar investor dapat mengambil keputusan yang tepat dalam berinvestasi pada perusahaan Otomotif dan Komponen.

\section{REFERENSI}

Anita, S., Suhendro, \& Anita, W. (2017). Pengaruh Profitabilitas Terhadap Harga Saham Perusahaan Manufaktur Sektor Makanan Dan Minuman Di Bei Tahun 2014 - 2015. Jurnal Akuntansi Dan Pajak, 18(01), 123-129. https://doi.org/10.29040/jap.v18i01.89

Anwar, Y., \& Rahmalia, L. (2019). The effect of return on equity, earning per share and price earning ratio on stock prices. The Accounting Journal of Binaniaga, 4(01), 57. https://doi.org/10.33062/ajb.v4i01.360

Arifin, N. F., \& Agustami, S. (2017). Pengaruh likuiditas, solvabilitas, profitabilitas, rasio pasar, dan ukuran perusahaan terhadap harga saham (Studi Pada Perusahaan Subsektor Perkebunan yang Terdaftar Di Bursa Efek Indonesia Tahun 2010-2014). Jurnal Riset Akuntansi Dan Keuangan, 4(3), 1189-1210. https://doi.org/10.17509/jrak.v4i3.4673

Asman, J., Ruliana, T., \& Suroso, A. (2015). Pengaruh Likuiditas dan Profitabilitas terhadap Harga Saham pada Perusahaan yang terdaftar di Bursa Efek Indonesia SUB Sektor Pakan Ternak tahun 2010 - 2015. Jurnal Akuntansi Dan Pajak, 151, 10-17. https://doi.org/10.1145/3132847.3132886

Asmirantho, E., \& Somantri, O. K. (2017). the Effect of Financial Performance on Stock Price At Pharmaceutical Sub-Sector Company Listed in Indonesia Stock Exchange. JIAFE (Jurnal Ilmiah Akuntansi Fakultas Ekonomi), 3(2), 94-107. https://doi.org/10.34204/jiafe.v3i2.778

Azmy, A. (2019). Analisis Pengaruh Rasio Keuangan Terhadap Harga Saham Perusahaan RE \& Properti Di Indonesia. Jurnal Riset Manajemen Sains Indonesia (JRMSI), 10(2). 94-107

Dewi, A. K., Purnomo, H., \& Murniati, W. (2016). Pengaruh Return On Assets 
(Roa), Return On Equity (Roe), dan Economic Value Added (Eva) Terhadap Harga Saham Perusahaan yang Tergabung dalam Jakarta Islamic Index Periode 2014 - 2016. Jurnal Akuntansi, 1(2). 97-109.

Dewi, P. D. A., \& Suayana, I. G. N. . (2013). Pengaruh Eps, Der, Dan Pbv Terhadap Harga Saham. Akuntansi Universitas Udayana, 1(3), 215-229

Farid, D. (2013). Pengaruh Rasio Profitabilitas dan Rasio Pasar Terhadap Harga Saham Perusahaan Tercantum Di Indeks LQ45. Jurnal Ilmiah STIE Perbanas, $3(3), 1-12$.

Febrioni, R. (2016). Pengaruh Return On Assets, Return On Equity, Earning Per Share, Dan Current Ratio Terhadap Return Saham (Pada Perusahaan Yang Terdaftar Di Indeks LQ45 Di Bursa Efek Indonesia Tahun 2011-2015). EProceeding of Management, 3(3), 3439-3449.

Gustmainar, J., \& Mariani. (2018). Analysis Of The Effect of Current Ratio, Debt to Equity Ratio, Gross Profit Margin, Return On Investment, and Earning Per Share On Stock Prices at LQ 45 Companies Listed On The Indonesia Stock Exchange In The Year Of 2010-2016. Bilancia, 2(4), 465-476. https://doi.org/2549-5704

Hasan, H. (2018). Random Effect Vs Fixed Effect Stock Price of Banking Sector. International Journal of Economics, Business and Management Research, 2(04), 192-208.

Hidayat, D. (2018). Pengaruh Kinerja Keuangan Terhadap Harga Saham ( Studi Pada Perusahaan Pertambangan Subsektor Pertambangan Minyak Dan Gas Bumi Yang Terdaftar Dibursa Efek Indonesia Periode 2013-2016 ). Jurnal Akuntansi, 62(1), 36-44.

Husnan, S., \& Pudjiastusi, E. (2012). Dasar-Dasar Manajemen Keuangan. Yogyakarta: UPP STIM YKPN.

Husnan, S., \& Pudjiastuti, E. (2015). Dasar - Dasar Manajemen Keuangan. Yogyakarta: UPP STIM YKPN.

Idamanti, N. (2013). Pengaruh Likuiditas, Profitabilitas dan Penjualan terhadap harga saham perusahaam makanan dan minuman yang tercatat di bursa efek indonesia tahun 2010-2014. Journal of Chemical Information and Modeling, 53(9), 1689-1699. https://doi.org/10.1017/CBO9781107415324.004

Idawati, W., \& Wahyudi, A. (2015). Effect of Earning Per Share (EPS) and Return On Assets (ROA) Against Share Price on Coal Mining Company Listed in Indonesia Stocks Exchange. Journal of Resource Development and Management, 7(1), 79-92. 
Igbinosa, S. O., \& Uhunmwangho, M. (2019). Macroeconomic Aggregates and Stock Market Liquidity : Evidence from African Stock Markets. International Journal of Economics and Financial Management, 4(1), 18-27.

Imelda, Wibowo, A. S., \& Diarsyad, M. I. (2018). Pengaruh Current Ratio , Cash Ratio , Return on Equity Dan Return on Aseet Terhadap Harga. Jurnal Akuntansi, 4(1), 0-25. https://doi.org/10.13140/RG.2.2.28935.04005

Kai, K. De, Bin, I., \& Rahman, A. (2018). The Impact of Financial Indicators towards Stock Returns of Finance Companies Listed on Bursa Malaysiae. International Journal of Academic Research in Accounting, Finance and Management Sciences, 8(3), 128-140. https://doi.org/10.6007/IJARAFMS/v8-i3/4546

Kumalasari, D., \& Pratikto, H. (2018). Good Corporate Governance Affects on Corporate Value Through Return on Equity and Return on Asset of Manufacture Company. 1st IRCEB, 1(1), 1-20. https://doi.org/10.18502/kss.v3i3.1878

Mareta, A. Dela, Administrasi, F. I., Brawijaya, U., Ratio, D., Equity, R. O., \& Leverage, F. (2013). Pengaruh financial leverage terhadap profitabilitas. Jurnal Akuntansi, 4(1), 1-20.

Mudjiyono. (2012). Pengertian Investasi. Jurnal STIE Semarang, 4(2), 1-18. https://doi.org/10.1039/c6ta04325a

Nalurita, F. (2019). Impact of Eps on Market Prices and Market Ratio. Business and Entrepreneurial Review, 15(2), 111. https://doi.org/10.25105/ber.v15i2.4629

Nurfadillah, M. (2011). Analisis Pengaruh Earning Per Share, Debt To Equity Ratio dan Return On Equity Terhadap Harga Saham PT. Unilever Indonesia Tbk. Jurnal Manajemen Dan Akuntansi, 12(1), 1-20.

Paramitasari, R. (2014). Analisis Faktor-Faktor Yang Mempengaruhi Audit Delay Pada Perusahaan Lq45 Yang Terdaftar Di Bursa Efek Indonesia. Jurnal Akuntansi Dan Bisnis, 14(1), 129-140. https://doi.org/10.20961/jab.v14i1.149

Pomartia, tiwuk zadri, JMV.Mulyadi, \& Rachbini, W. (2019). Analisis Volatilitas Harga Saham dengan ROA dan ROE sebagai Variabel Kontrol. Journal of Chemical Information and Modeling, 53(9), 1689-1699. https://doi.org/10.1017/CBO9781107415324.004

Pratama, C. A.. (2019). Pengaruh Return On Equity (ROE), Earning Per Share (EPS), Current Ratio (CR) dan Debt to Equity Ratio (DER) Terhadap Harga 
Saham. Jurnal Administrasi Bisnis, 66(1), 10-17.

Rahayu, N. M. P. S., \& Dana, I. M. (2016). Pengaruh Eva, Mva Dan Likuiditas Terhadap Harga Saham Pada Perusahaan Food and Beverages. E-Jurnal Manajemen Universitas Udayana, 5(1), 443-469.

Rahmadewi, P. W., \& Abundanti, N. (2018). Pengaruh Eps, Per, Cr Dan Roe Terhadap Harga Saham Di Bursa Efek Indonesia. E-Jurnal Manajemen Universitas Udayana, 7(4), 2106. https://doi.org/10.24843/ejmunud.2018.v07.i04.p14

Rosikah. (2018). Effects of Return on Asset, Return On Equity, Earning Per Share on Corporate Value. The International Journal of Engineering and Science (IJES, 7(3), 6-14. https://doi.org/10.9790/1813-0703010614

Sari, S. O. D., \& Herawati, V. (2019). Pengaruh rasio pasar, profitabilitas, leverage, likuiditas dan aktivitas terhadap kinerja pasar dengan corporate governance sebagai pemoderasi. Jurnal Administrasi Bisnis, 66(1), 1-6.

Sawir, A. (2012). Analisa Kinerja Keuangan dan Perencanaan keuangan Perusahaan. Jakarta: PT. Gramedia Pustaka Utama.

Sha, T. L. (2017). Effects of Price Earnings Ratio, Earnings Per Share, Book to Market Ratio and Gross Domestic Product on Stock Prices of Property and Real Estate Companies in Indonesia Stock Exchange Thio Lie SHA. International Journal of Economic Perspectives, 11(1), 1743-1754.

Sitorus, T., \& Elinarty, S. (2017). The Influence of Liquidity and Profitability toward the growth of Stock price mediated by the Dividen Paid out (Case in banks listed in Indonesia Stock Exchange). Journal of Economics, Business \& Accountancy Ventura, 19(3), 377-392. https://doi.org/10.14414/jebav.v19i3.582

Susyanti, F. N. J., \& Salim, M. A. (2019). Pengaruh Saham Syariah, Obligasi Syariah, Dan Reksadana Syariah Terhadap Reaksi Pasar Modal Di Indonesia. Jurnal Riset Manajemen, 8(4), 82-94.

Utami, M. R., \& Darmawan, A. (2019). Effect of DER , ROA , ROE , EPS and MVA on Stock Prices in Sharia Indonesian Stock Index. Journal Of Applaied Accounting and Taxation, 4(1), 15-22.

Viet Ha, H. T., Hung, D. N., \& Dung, T. M. (2018). Impact of Accounting Data on Stock Prices: The Case of Vietnam. International Journal of Accounting and Financial Reporting, 8(1), 140. https://doi.org/10.5296/ijafr.v8i1.12671

Warrad, L. H. (2017). The Effect of Market Valuation Measures on Stock Price: 
Ni Kadek Anggun Pramesthi Dewi Sujata, Rasio Pasar, Profitabilitas...

An Empirical Investigation on Jordanian Banks. International Journal of Business and Social Science, 8(3), 67-74.

Watung, R., \& Ilat, V. (2016). Pengaruh Return on Asset (Roa), Net Profit Margin (Npm), Dan Earning Per Share (Eps) Terhadap Harga Saham Pada Perusahaan Perbankan Di Bursa Efek Indonesia Periode 2011-2015. Jurnal Riset Ekonomi, Manajemen, Bisnis Dan Akuntansi, 4(2), 518-529.

Wehantouw, J. D., Tommy, P., \& Tampenawas, J. L. . (2017). Pengaruh Struktur Modal, Ukuran Perusahaan, Dan Profitabilitas Terhadap Harga Saham Pada Perusahaan Industri Sektor Makanan Dan Minuman Yang Terdaftar Di Bursa Efek Indonesia Periode 2012-2015. Jurnal EMBA: Jurnal Riset Ekonomi, Manajemen, Bisnis Dan Akuntansi, 5(3), 3385-3394.

Wiagustini, N. L. P. (2013). Dasar-dasar Manajemen Keuangan. Denpasar: Udayana University Press.

Wulandari, A. I., \& Badjra, I. B. (2019). Pengaruh Profitabilitas Terhadap Harga Saham Pada Perusahaan Lq-45 Di Bursa Efek Indonesia (Bei). E-Jurnal Manajemen Universitas $\quad$ Udayana, $8(9), \quad 5722$. https://doi.org/10.24843/ejmunud.2019.v08.i09.p18

Yuliza, A. (2018). The Effects of Earnings Per Share and Firm Size to Stock Price LQ45 Company Listed in Indonesian Securities. International Journal of $\begin{array}{lllll}\text { Engineering } \quad \& \quad \text { Technology, } & \text { 7(4.9), }\end{array}$ https://doi.org/10.14419/ijet.v7i4.9.21089

Zuhroh, I. (2019). The Effects of Liquidity, Firm Size, and Profitability on the Firm Value with Mediating Leverage. KnE Social Sciences, 1(2), 1-10. 